\title{
Evaluation of Composts for Suppression of Dollar Spot (Sclerotinia homoeocarpa) of Turfgrass
}

\author{
Jeanine I. Boulter, Greg J. Boland, and Jack T. Trevors, Department of Environmental Biology, University of \\ Guelph, Guelph, Ontario, Canada, N1G 2W1
}

\begin{abstract}
Boulter, J. I., Boland, G. J., and Trevors, J. T. 2002. Evaluation of composts for suppression of dollar spot (Sclerotinia homoeocarpa) of turfgrass. Plant Dis. 86:405-410.

The use of composts in turfgrass disease management allows for a reduction in pesticide use in chemical control practices. Disease suppressive properties of composts rely on a number of factors including microbial activity, microbial population dynamics, nutrient concentrations, and other associated chemical and physical factors. Five composts were evaluated for suppression of dollar spot caused by Sclerotinia homoeocarpa. The dollar spot disease suppressive properties of selected compost formulations prepared in different years was evaluated. A third objective was to examine the effects of storage of compost (1 year) on the suppression of dollar spot. Field experiments were conducted in 1998 with compost prepared in 1997 to 1998. Applications of compost every 3 weeks throughout the season suppressed dollar spot of turf to levels not significantly different than applications of chlorothalonil fungicide applied at the manufacturer's lowest recommended preventative rate of $38.4 \mathrm{ml}$ a.i./100 $\mathrm{m}^{2}$ every 2 weeks $(P=0.05)$. Single applications of composts at the start of the 1998 season were not effective in reducing disease. Field experiments in 1999 evaluated batches of two selected compost formulations, one batch produced in 1998 to 1999, another stored since production in 1997 to 1998 . Composts were effective in suppressing disease to levels not significantly different than the fungicide controls, which showed up to $33 \%$ disease in 1998 and up to $31 \%$ disease in $1999(P=0.05)$. Storage of composts for up to 1 year did not affect their ability to reduce dollar spot severity $(P$ $=0.05$ ). The use of composts as plant disease suppressants is not likely to replace the use of commercial fungicides in dollar spot management. However, multiple applications of compost may reduce incidence and severity of dollar spot to levels at which chemical control may be reduced or eliminated for a significant portion of the season.
\end{abstract}

Additional keywords: Agrostis palustris, creeping bentgrass, organic amendments, turf

Dollar spot, caused by Sclerotinia homoeocarpa F.T. Bennett, is an important turfgrass disease (41). More money is spent on controlling dollar spot than any other turf disease of golf courses (11). Although fungicides are commonly used for its management, the need for high frequency of applications, associated costs, nontarget effects, development of fungicide resistant populations, and perceived health risks to humans and the surrounding environment has stimulated the search for alternative methods of disease management $(7,30)$. Cultural controls are also utilized as management strategies and dollar spot may be partially controlled with applications of nitrogen and thorough but infrequent wa-

Corresponding author: Jeanine I. Boulter E-mail: jboulter@uoguelph.ca

This research was supported by an Industrial Research Assistance Program (IRAP) to All Treat Farms, Arthur, Ontario, Canada. Research by G. J. Boland and J. T. Trevors is also supported by NSERC (Canada) operating grants.

Accepted for publication 26 November 2001.

Publication no. D-2002-0219-01R

(C) 2002 The American Phytopathological Society tering $(6,37)$. An exciting alternative in turfgrass disease management is the development and use of organic amendments such as composts, organic fertilizers, and sludges, or inoculation of turf with specific bacterial or fungal species known to suppress disease (2).

The use of composts and other organic amendments for disease suppression has the potential to be beneficial in reducing fungicide use. Although compost may not control turfgrass diseases to a level that will replace the use of fungicides, their integration into current disease management practices may reduce the use of fungicides. Naturally suppressive composts can be integrated into normal golf course maintenance programs by using composts to replace sphagnum peat or other organic materials used in top-dressing mixtures.

Composts are known to suppress plant diseases through a combination of physiochemical and biological mechanisms. Physiochemical factors such as nutrient levels, organic matter, moisture, and $\mathrm{pH}$ reduce disease severity by directly or indirectly affecting the pathogen or host capacity for growth $(12,24,42)$. Biological factors include microbial populations in compost, microbial competition for nutrients with pathogens $(4,5,16)$, antibiotic production $(30,42)$, production of lytic and other extracellular enzymes $(19,25,26)$, parasitism and predation $(3,15)$, and induction of host-mediated resistance in plants (27).

Dollar spot is one of the more commonly studied diseases for suppression with composts, sludges, and other organic materials $(17,20,23,31,33)$. Sustane turkey litter compost (Sustane Corporation, Cannon Falls, MN) and sludge composts provided some suppression of dollar spot (33). The organic fertilizers, Harmony/KLM and Ringer Commercial Greens Super, and the synthetic fertilizers, urea and Nitroform, provided similar levels of dollar spot disease suppression (17). Compost can be a beneficial material where a high proportion of organic matter may offset sand content and increase or restore microbial populations (1). High levels of microbial activity in composts were postulated as the primary factor in disease control $(8,9,28,29,31-$ $33,35)$. Several bacterial and fungal species that have been found in composts (e.g., Fusarium heterosporum, Acremonium spp., Rhizoctonia spp., Enterobacter cloacae, Pseudomonas fluorescens, and Pseudomonas lindbergii) are known to be highly antagonistic to dollar spot $(11,13,29)$. However, physiochemical factors, which include fertilizer effects and other factors, are often implicated in control $(11,38)$. Microbial populations in compost are thought to provide nutrients and other chemical compounds to pathogencompeting microorganisms and plant hosts through continual breakdown of composted material $(18,31)$. There are several examples where nutrient competition was a factor in suppression of plant pathogens $(5,8,10,16,21,27,34,40,42)$. For example, nitrogen, a known cultural control method for dollar spot, is considered partially or even completely responsible for dollar spot control with composts and other natural organic fertilizers (23).

The lifespan of usefulness of biologically active products such as compost has been an area of concern. Changes in microbiological activity in stored compost may affect suppression of pathogens when competitive and antagonistic effects of microbial populations are suspected mechanisms of disease control.

One objective of this study was to evaluate the ability of five commercially available composts, top-dressed on creeping bentgrass (Agrostis palustris) putting greens at selected application rates and 
frequencies to suppress dollar spot. A second objective was to evaluate the dollar spot disease suppressive properties of selected compost formulations prepared in different years. A third objective was to examine the effects of storage of compost (1 year) on the suppression of dollar spot.

\section{MATERIALS AND METHODS}

Preparation of composts. Five mature composts (as determined by nutrient analysis and continual monitoring of temperature and oxygen levels) were provided by All Treat Farms, Ltd., Arthur, ON, Canada. Composts 4, 5, 6, 8, and 9 (Table 1) were prepared during 1997 and 1998, and composts 6 and 9 were prepared a second time during 1998 and 1999. Composts used in plant disease suppression assays were produced using proprietary blends of selected feedstocks combined in proportions that would result in acceptable $\mathrm{C}: \mathrm{N}$ ratios and moisture levels. Feedstock nutrient analyses and components are listed in Table 1. The beginning of the composting process was defined as day 0 , and ranged from 19 June to 4 July 1997, and 22 to 24 September 1998 for 1998 and 1999 experiments, respectively. There were five composts prepared in this manner, and all were passively aerated over a period of approximately 32 weeks, during which the compost piles were mechanically turned once to remix materials. Passive aeration involved a means of accelerated air movement by placing compost piles on perforated pads that allowed air to diffuse upward into the base of the pile and exit through the top. The composting process was stopped when the average core compost temperature declined to at least $45^{\circ} \mathrm{C}$. In addition, each compost had to achieve pathogen-kill temperatures of $>55^{\circ} \mathrm{C}$, and remain at these temperatures for $>5$ days. All composts were screened to $3.8 \mathrm{~mm}$ particle size before application.
Pathogen inoculum and preparation. S. homoeocarpa (isolate Sh48B) was maintained on potato dextrose agar (PDA, Bacto, Difco Laboratories, Detroit, MI) at $4^{\circ} \mathrm{C}$. For preparation of field inoculum, $S$. homoeocarpa was initially grown on agar plates of PDA at $22 \pm 2^{\circ} \mathrm{C}$ for 9 days and transferred (20 plugs of $5 \mathrm{~mm}$ diameter from the colony margin) into $1,000-\mathrm{ml}$ Erlenmeyer flasks containing $250 \mathrm{ml}$ of sterile chicken scratch (corn, barley, oats) mix plus $100 \mathrm{ml}$ deionized water (2.5:1 $\mathrm{wt} / \mathrm{wt})$. Inoculated flasks were incubated at $21 \pm 2^{\circ} \mathrm{C}$ until thoroughly colonized at 21 days. Seventy-two hours before field inoculation, the medium was removed from the flasks, placed on paper towels in a laminar flow cabinet, and air-dried for 48 h. Inoculum was then ground in a Waring blender (Model 5011, Waring Products Division, New Hartford, CT), weighed, and placed in individual envelopes for field application. Inoculum was applied by hand to plots at a rate of $1 \mathrm{~g} / \mathrm{m}^{2} 3$ days prior to compost top-dressings.

Experiments. Field plots were established on a 4- to 5-year-old creeping bentgrass (Agrostis palustris Pencross) green in 1998 and 1999 at the Guelph Turfgrass Institute, Guelph, ON, Canada, to evaluate the ability of compost to suppress dollar spot. The green had been constructed to the United States Golf Association specifications using $80 \%$ sand. Sulfur-coated urea (N-P-K: 25-4-10) was applied at a rate of $2 \mathrm{~kg} / 100 \mathrm{~m}^{2}$ in April and November annually. Mowing height during the growing season was set at $4 \mathrm{~mm}$. Plots were mowed daily with clippings removed. The green was irrigated as needed. Initial soil $\mathrm{pH}$ was 7.2.

Experiment 1-1998. Field plots $(1 \times 2$ $\mathrm{m})$ of creeping bentgrass were maintained under golf course putting green conditions. In 1998, the factorial experiment (composts and rates of application) with four replications per treatment included a split block design (22) to evaluate single and multiple applications of compost. As a result, the $1 \times 2 \mathrm{~m}$ plots were subdivided into two $1 \times 1 \mathrm{~m}$ plots: one half received a single compost application, while the other half had compost applied every 3 weeks for the duration of the experiment. All plots received inoculum at a rate of $1 \mathrm{~g} / \mathrm{m}^{2}$. The five composts were applied as topdressing at $12.2,24.4$, and $48.7 \mathrm{~kg}$ (dry weight $) / 100 \mathrm{~m}^{2}(25,50$, and $100 \mathrm{lb} / 1,000$ $\mathrm{ft}^{2}$ ). There was a pathogen only control. In addition, the commercial fungicide Daconil 2787 (chlorothalonil, tetrachloroisophthalonitrile 40.4\%) (ISK Biotech Corporation, Mantor, OH, Reg. No. 15 724) was applied as a separate treatment every 14 days at the lowest manufacturer's recommended preventative rate of $95 \mathrm{ml} / 100 \mathrm{~m}^{2}(38.4 \mathrm{ml}$ a.i./100 $\mathrm{m}^{2}$ ) with a portable compressed $\mathrm{CO}_{2}$ sprayer at $301.2 \mathrm{kPa}$, using a TeeJet 8002VS nozzle. Experimental setup involved initial applications of inoculum on 9 July, and compost and fungicide on 12 July 1998, 3 weeks prior to the first rating date for dollar spot severity. Plots were rated weekly for dollar spot severity for a period of 10 weeks.

Experiment 2-1999. In 1999, a factorial experiment with four replications $(1 \times$ $2 \mathrm{~m}$ plots) per treatment was used to evaluate composts 6 and 9 prepared in 1999, as well as composts 6 and 9 prepared in 1998 for dollar spot suppression. Experiments in 1999 were designed to assess the dollar spot suppressive effects of composts 6 and 9 , as well as evaluate the storage effects on suppressive capabilities. Stored composts were kept in 25 -liter plastic bags with $2 \%$ of the surface area punctured with holes to allow for air exchange. Bagged compost was kept in an unheated storage facility (no exposure to sunlight) for the duration of the 1-year storage period. Ambient temperatures ranged from $25^{\circ} \mathrm{C}$ in the summer to $-15^{\circ} \mathrm{C}$ in the winter. Composts were applied every 3 weeks for the duration of

Table 1. Composition and nutrient analysis of composts 4, 5, 6, 8, and 9 produced during 1997 and 1998, and composts 6 and 9 produced a second time during 1998 and 1999

\begin{tabular}{|c|c|c|c|c|c|c|c|}
\hline \multirow[b]{3}{*}{ Feedstocks } & \multicolumn{7}{|c|}{ Compost } \\
\hline & \multicolumn{5}{|c|}{1997 to 1998} & \multicolumn{2}{|c|}{1998 to 1999} \\
\hline & 4 & 5 & 6 & 8 & 9 & 6 & 9 \\
\hline Horse manure & & & & $\mathrm{X}$ & & & \\
\hline Chicken manure & $\mathrm{x}$ & $\mathrm{x}$ & $\mathrm{x}$ & $\mathrm{x}$ & $\mathrm{x}$ & $\mathrm{x}$ & $\mathrm{x}$ \\
\hline Paunch manure ${ }^{\mathrm{x}}$ & & & & & $\mathrm{x}$ & & $\mathrm{x}$ \\
\hline Bone meal ash & & & $\mathrm{x}$ & $\mathrm{x}$ & & $\mathrm{x}$ & \\
\hline Bark mix & $\mathrm{x}$ & $\mathrm{x}$ & $\mathrm{x}$ & $\mathrm{X}$ & $\mathrm{x}$ & $\mathrm{X}$ & $\mathrm{x}$ \\
\hline Soybean meal & & $\mathrm{x}$ & $\mathrm{x}$ & $\mathrm{x}$ & & $\mathrm{x}$ & \\
\hline Milorganite & & $\mathrm{x}$ & $\mathrm{x}$ & $\mathrm{X}$ & & $\mathrm{x}$ & \\
\hline Moisture (\%) & 41.72 & 38.71 & 43.97 & 42.29 & 53.41 & 40.60 & 44.70 \\
\hline $\mathrm{C}: \mathrm{N}$ ratio & 28.54 & 31.96 & 24.12 & 27.45 & 29.22 & 24.12 & 29.22 \\
\hline $\mathrm{NH}_{4}(\mathrm{mg} / \mathrm{kg})$ & 162.4 & 125.0 & 242.0 & 156.0 & 83.0 & 235.2 & 84.1 \\
\hline $\mathrm{NO}_{3}(\mathrm{mg} / \mathrm{kg})$ & 86.2 & 103.0 & 98.8 & 35.6 & 75.0 & 104.1 & 82.1 \\
\hline $\mathrm{NO}_{2}(\mathrm{mg} / \mathrm{kg})$ & $<0.1$ & $<0.1$ & $<0.1$ & $<0.1$ & $<0.1$ & $<0.1$ & $<0.1$ \\
\hline Total N (mg/kg) & 6260 & 6900 & 8030 & 6340 & 6280 & 8120 & 6340 \\
\hline Organic N (mg/kg) & 5945 & 6672 & 7689 & 6149 & 6122 & 7856 & 6053 \\
\hline
\end{tabular}

\footnotetext{
$x$ Paunch manure refers to feed remaining in the rumens of slaughtered cattle.
}

${ }^{y}$ Bone meal ash refers to the mineral remains of animal bone materials. 
the experiment. The four composts were top-dressed at 12.2, 24.4, and $48.7 \mathrm{~kg}$ (dry weight $) / 100 \mathrm{~m}^{2}$. There was a pathogen only control. The fungicide Daconil 2787 was also applied as in experiment 1 . Experimental set up involved initial applications of inoculum followed in 3 days by compost and fungicide applications 3 weeks prior to the first rating date for dollar spot severity. Plots were rated weekly for dollar spot severity for a period of 10 weeks.

Rating and data analysis. Plots were rated visually for dollar spot severity on the basis of percent $(0=$ no disease and $100=100 \%$ ) plot area exhibiting disease symptoms. Plots were rated beginning on the third week following initial application of compost due to absence of disease development prior to this date. Plots were rated weekly until the end of the season. Data were analyzed using Statistical Analysis Software (SAS Institute Inc., Cary, NC) as a factorial experiment, reducing the full model by the removal of nonsignificant terms $(P=0.05)$. Means were compared with Tukey's adjustment for multiple comparisons. Dunnett's test was used to compare each treatment to the pathogen and fungicide controls. For the 1998 field experiment, single and multiple applications (split block) were analyzed separately as the split plot $\times$ main plot interaction was significant. For 1998 and 1999 experiments, an area under the disease progress curve (AUDPC) was calculated for each treatment as a measure of cumulative disease incidence for the season using the equation:

$$
\mathrm{AUDPC}=3\left[\left(y_{i}+y_{i+1}\right)\left(t_{i+1}-t_{i}\right) / 2\right]
$$

for $i=1,2,3 \ldots, n-1$, where $y_{i}$ is the cumulative disease incidence expressed as a proportion at the $i$ th observation, and $t_{i}$ is the time (days after first compost treatment) at the $i$ th observation $(36,38)$.

\section{RESULTS}

Experiment 1-1998. The results of single and multiple applications of compost on the severity of dollar spot for 1998 are presented in Tables 2 and 3, respectively.

Single applications of compost did not provide any significant suppression of disease compared to the control for most of the season (Table 2). There were no significant differences between these treatments and the fungicide treatment until 63 days after treatment (DAT), when the fungicide treatment provided significantly increased control of disease. The AUDPC values indicated that all compost-rate single applications provided significantly less control of dollar spot than the fungicide treatment, and were not significantly different from the control. Disease severity ratings at 14 and 21 DAT were not analyzed due to negligible disease and because the second of multiple applications of compost was not conducted until 21 DAT.

Most compost treatments applied every 3 weeks reduced dollar spot severity compared to the untreated control on six of seven rating dates (Table 3). Although most multiple application treatments were not significantly different from each other, two (such as composts 8 and 9, at 48.7 $\mathrm{kg} / 100 \mathrm{~m}^{2}$ ) suppressed disease to significantly lower levels than the control plots for a large portion of the season. The AUDPC values showed that multiple applications of compost suppressed disease severity to levels that were not significantly different from the fungicide but were significantly lower than the control (except for three treatments). In addition, there was a trend among compost rates that showed decreased disease levels as compost application rate increased. This research indicated that applications of compost every 3 weeks reduced dollar spot severity as effectively as applications of chlorothalonil $\left(38.4 \mathrm{ml}\right.$ a.i./100 $\left.\mathrm{m}^{2}\right)$ every 2 weeks. However, disease levels in plots treated with chlorothalonil ranged from 4.7 to $33.3 \%$ of the plot area affected.

In general, compost treatments were not significantly different from each other. There were no differences among composts and application rates in either single or multiple applications (except for one treatment on one date). Because the fungicide treatment showed little control of disease until 63 DAT, selected multiple application treatments of composts showed significantly better control of disease than the fungicide, prior to 63 DAT. However, at 63 DAT, there was an improvement in dollar spot control with applications of fungicide. AUDPC values showed that

Table 2. Dollar spot severity (percent disease) in creeping bentgrass plots amended with five composts applied once at three rates in 1998 (each point is the average of $n=4)$

\begin{tabular}{|c|c|c|c|c|c|c|c|c|c|}
\hline \multicolumn{10}{|c|}{ Single application ${ }^{\mathrm{s}}$} \\
\hline \multirow[b]{2}{*}{ Compost $^{u}$} & \multirow[b]{2}{*}{ Rate $^{\mathrm{v}}$} & \multicolumn{8}{|c|}{ Days after treatment $(\text { DAT })^{t}$} \\
\hline & & 28 & 42 & 49 & 56 & 63 & 70 & 77 & AUDPC \\
\hline 4 & 1 & $15.3 \mathrm{a}^{\mathrm{w}}$ & $30.0 \mathrm{a}$ & $36.3 \mathrm{a}$ & $37.5 \mathrm{a}$ & $43.8 \mathrm{a} \dagger$ & $42.5 \mathrm{ab} \dagger$ & $42.5 \mathrm{a} \dagger$ & $1828.9 \mathrm{a}$ \\
\hline 4 & 2 & $23.0 \mathrm{a} \dagger \mathrm{x}$ & $33.8 \mathrm{a}$ & $42.5 \mathrm{a}$ & $36.3 \mathrm{a}$ & $41.3 \mathrm{a} \dagger$ & $50.0 \mathrm{ab} \dagger$ & $52.5 \mathrm{a} \dagger$ & $2072.1 \mathrm{a} \dagger$ \\
\hline 4 & 3 & $18.5 \mathrm{a}$ & $33.8 \mathrm{a}$ & $38.8 \mathrm{a}$ & $36.3 \mathrm{a}$ & $45.0 \mathrm{a} \dagger$ & $43.8 \mathrm{ab} \dagger$ & $50.0 \mathrm{a} \dagger$ & $1963.6 \mathrm{a} \dagger$ \\
\hline 5 & 1 & $14.5 \mathrm{a}$ & $33.8 \mathrm{a}$ & $37.5 \mathrm{a}$ & $35.0 \mathrm{a}$ & $43.8 \mathrm{a} \dagger$ & $45.0 \mathrm{ab} \dagger$ & $51.3 \mathrm{a} \dagger$ & $1911.0 \mathrm{a} \dagger$ \\
\hline 5 & 2 & $18.0 \mathrm{a}$ & $33.8 \mathrm{a}$ & $41.3 \mathrm{a}$ & $36.3 \mathrm{a}$ & $45.0 \mathrm{a} \dagger$ & $47.5 \mathrm{ab} \dagger$ & $50.0 \mathrm{a} \dagger$ & $2005.9 \mathrm{a} \dagger$ \\
\hline 5 & 3 & $18.8 \mathrm{a}$ & $38.8 \mathrm{a}$ & $45.0 \mathrm{a}$ & $36.3 \mathrm{a}$ & $50.0 \mathrm{a} \dagger$ & $47.5 \mathrm{ab} \dagger$ & $55.0 \mathrm{a} \dagger$ & $2150.0 \mathrm{a} \dagger$ \\
\hline 6 & 1 & $14.3 \mathrm{a}$ & $25.0 \mathrm{a}$ & $35.0 \mathrm{a}$ & $23.8 \mathrm{a}$ & $36.3 \mathrm{a} \dagger$ & $43.8 \mathrm{ab} \dagger$ & $50.0 \mathrm{a} \dagger$ & $1652.1 \mathrm{a} \dagger$ \\
\hline 6 & 2 & $14.3 \mathrm{a}$ & $37.5 \mathrm{a}$ & $37.5 \mathrm{a}$ & $37.5 \mathrm{a}$ & $50.0 \mathrm{a}^{\dagger}$ & $51.3 \mathrm{ab} \dagger$ & $55.0 \mathrm{a} \dagger$ & $2075.9 \mathrm{a}$ \\
\hline 6 & 3 & $20.0 \mathrm{a}$ & $38.8 \mathrm{a}$ & $42.5 \mathrm{a}$ & $38.8 \mathrm{a}$ & $48.8 \mathrm{a} \dagger$ & $48.8 \mathrm{ab} \dagger$ & $50.0 \mathrm{a} \dagger$ & $2141.9 \mathrm{a} \dagger$ \\
\hline 8 & 1 & $16.8 \mathrm{a}$ & $33.8 \mathrm{a}$ & $38.8 \mathrm{a}$ & $38.8 \mathrm{a}$ & $40.0 \mathrm{a} \dagger$ & $48.8 \mathrm{ab} \dagger$ & $52.5 \mathrm{a} \dagger$ & $1979.0 \mathrm{a} \dagger$ \\
\hline 8 & 2 & $14.5 \mathrm{a}$ & $33.3 \mathrm{a}$ & $38.8 \mathrm{a}$ & $37.5 \mathrm{a}$ & $45.0 \mathrm{a} \dagger$ & $40.0 \mathrm{abc}$ & $50.0 \mathrm{a} \dagger$ & $1895.1 \mathrm{a} \dagger$ \\
\hline 8 & 3 & $15.3 \mathrm{a}$ & $30.0 \mathrm{a}$ & $37.5 \mathrm{a}$ & $30.0 \mathrm{a}$ & $40.0 \mathrm{a} \dagger$ & $46.3 \mathrm{a} \dagger$ & $45.0 \mathrm{a} \dagger$ & $1800.1 \mathrm{a} \dagger$ \\
\hline 9 & 1 & $19.5 \mathrm{a}$ & $32.5 \mathrm{a}$ & $41.3 \mathrm{a}$ & $33.8 \mathrm{a}$ & $40.0 \mathrm{a} \dagger$ & $26.3 \mathrm{bc} \ddagger$ & $53.8 \mathrm{a} \dagger$ & $1962.9 \mathrm{a} \dagger$ \\
\hline 9 & 2 & $15.8 \mathrm{a}$ & $31.3 \mathrm{a}$ & $40.0 \mathrm{a}$ & $36.3 \mathrm{a}$ & $40.0 \mathrm{a} \dagger$ & $23.8 \mathrm{c} \ddagger$ & $45.0 \mathrm{a} \dagger$ & $1799.8 \mathrm{a} \dagger$ \\
\hline 9 & 3 & $15.8 \mathrm{a}$ & $30.0 \mathrm{a}$ & $42.5 \mathrm{a}$ & $35.0 \mathrm{a}$ & $45.0 \mathrm{a} \dagger$ & $52.5 \mathrm{a} \dagger$ & $53.8 \mathrm{a} \dagger$ & $1999.8 \mathrm{a} \dagger$ \\
\hline Pathogen ${ }^{y}$ & & 13.3 & 30.8 & 33.8 & 31.3 & 38.8 & 37.5 & 38.8 & 1781.6 \\
\hline Fungicide $^{\mathrm{z}}$ & & 9.3 & 26.7 & 33.3 & 28.3 & 4.7 & 11.7 & 16.7 & 1029.3 \\
\hline
\end{tabular}

\footnotetext{
s Single application refers to the portion of the split plot experimental design that received one compost application.

${ }^{\mathrm{t}}$ DAT (days after treatment) refers to rating date when disease severity was assessed after initial experimental set up. Disease was rated in percent of total plot area diseased.

u Compost refers to compost $4,5,6,8$, or 9 .

${ }^{v}$ Compost application rate: $1=12.2 \mathrm{~kg} / 100 \mathrm{~m}^{2}, 2=24.4 \mathrm{~kg} / 100 \mathrm{~m}^{2}$, and $3=48.7 \mathrm{~kg} / 100 \mathrm{~m}^{2}$.

w Values followed by the same letter(s) within individual columns are not statistically different at $P=0.05$, as tested using an analysis of variance followed by Tukey's test.

${ }^{x}$ Values followed by the same symbols $(\dagger$ and $\ddagger)$ within individual columns represent treatments that are statistically different $(P=0.05)$ from the fungicide and pathogen controls, respectively.

y Pathogen refers to the level of disease in control plots inoculated with the pathogen only.

${ }^{\mathrm{z}}$ Fungicide refers to the level of disease in control plots treated with the pathogen and a fungicide only.
} 
there were no significant differences $(P=$ 0.05 ) among the compost treatments when applied either in single or multiple applications, but plots treated with higher rates of compost showed trends towards having less disease than plots treated with the lower rates for the multiple application treatments.

Experiment 2-1999. Plots treated with compost developed significantly less dollar spot compared to the control plots for most of the 1999 season (Table 4). There were some significant differences among disease severity ratings in plots treated with compost applied at different rates, although there were no consistent differences among composts. Compost treatments that suppressed disease to levels significantly lower than the control plots for most of the season mainly involved the highest application rates (i.e., $48.7 \mathrm{~kg} / 100 \mathrm{~m}^{2}$ ). Almost all compost treated plots suppressed dollar spot severity to levels not significantly different than the fungicide treatments for the season. Fungicide treated plots showed a similar trend in disease control compared as in 1998, when an apparent lack of control at the start of the season was followed by an improvement in dollar spot control by the end of the season. Based on AUDPC values, all compost treatments except one, suppressed disease severity to the same levels as the fungicide treatment and all provided significantly decreased disease severity compared to the control.

These results indicate that applications of compost every 3 weeks reduced dollar spot severity as effectively as applications of fungicide every 2 weeks. In addition, storage of compost for up to 1 year does not appear to alter its ability to control dollar spot of turf.

\section{DISCUSSION}

Field experiments in 1998 and 1999 were effective in identifying multiple applications (every 3 weeks) of compost as a suppressant to dollar spot. Although AUDPC showed that all compost treatments (except one) were as effective as the fungicide, there were some significant differences among rates of application over the season. The highest rate of compost applied $\left(48.7 \mathrm{~kg} / 100 \mathrm{~m}^{2}\right)$ was better at suppressing dollar spot than the lowest rate of application $\left(12.2 \mathrm{~kg} / 100 \mathrm{~m}^{2}\right)$, especially in the 1999 field season. In contrast, Hoitink (14) found higher rates of compost application to be no better than lower rates in disease suppression, suggesting that smaller amounts of organic matter were sufficient to stimulate the microbiota.

Unusually poor performance (up to $33 \%$ disease injury) of chlorothalonil treatments may have been a result of the low application rate selected for field studies. Manufacturer recommendations suggested a preventative application rate of 95 to 190 $\mathrm{ml} / 100 \mathrm{~m}^{2}$ (38.4 to $76.8 \mathrm{ml}$ a.i./100 $\mathrm{m}^{2}$ ), and a curative application rate of 190 to $350 \mathrm{ml}$ a.i. $/ 100 \mathrm{~m}^{2}$ (76.8 to $141.4 \mathrm{ml}$ a.i./100 $\mathrm{m}^{2}$ ). In these experiments, chlorothalonil was applied at the lowest preventative recommended rate of 95 $\mathrm{ml} / 100 \mathrm{~m}^{2}$ (38.4 $\mathrm{ml}$ a.i./100 $\mathrm{m}^{2}$ ). Improved levels of dollar spot control would have likely been observed if higher rates of application specifically into the recommended curative rates were chosen. Alternatively, chlorothalonil could have been applied at the preventative rate initially (recommended when disease conditions are light to moderate), and switched to levels into curative rate range when conditions were severe. Also, the manufacturer recommended increasing the frequency of applications from every 14 days to every 7 days under severe disease conditions. The preventative rate and timing chosen, $95 \mathrm{ml}$ (38.4 $\mathrm{ml}$ a.i./100 $\mathrm{m}^{2}$ ) every 2 weeks was selected based on studies by other researchers in the same geographical area, where preventative rates were effective in dollar spot control (20). However, microclimate effects likely played a larger role than anticipated in increasing disease severity.

Calculation of the AUDPC was a useful method for determining cumulative disease as it incorporated the sum of effects over time that may not be detected on individual rating dates. This method of comparing seasonal disease values may be more useful for assessing disease control methods where effects on pathogens may be more subtle, additive, or cumulative, or require a time period to become adequately active. AUDPC may be especially useful with compost amendments, where time is likely a factor in suppression, because suppression may require growth and adaptation of

Table 3. Dollar spot severity (percent disease) in creeping bentgrass plots amended with five composts applied every 3 weeks at three rates in 1998 (each point is the average of $n=4$ )

\begin{tabular}{|c|c|c|c|c|c|c|c|c|c|}
\hline \multicolumn{10}{|c|}{ Multiple applications ${ }^{s}$} \\
\hline \multirow[b]{2}{*}{ Compost $^{u}$} & \multirow[b]{2}{*}{ Rate $^{v}$} & \multicolumn{8}{|c|}{ Days after treatment (DAT) ${ }^{\mathrm{t}}$} \\
\hline & & 28 & 42 & 49 & 56 & 63 & 70 & 77 & AUDPC \\
\hline 4 & 1 & $6.0 \mathrm{a}^{\mathrm{w}}$ & $18.0 \mathrm{a}$ & $28.8 \mathrm{a}$ & $25.0 \mathrm{a}$ & $30.0 \mathrm{a} \dagger$ & $28.8 \mathrm{ab} \dagger \ddagger$ & $35.0 \mathrm{a} \dagger$ & $1285.5 \mathrm{a}$ \\
\hline 4 & 2 & $2.5 \mathrm{a} \ddagger^{\mathrm{x}}$ & $21.3 \mathrm{a}$ & $22.5 \mathrm{a}$ & $22.5 \mathrm{a}$ & $22.5 a \dagger$ & $22.5 \mathrm{a} \neq$ & $32.5 \mathrm{a}$ & $1109.4 \mathrm{a} \neq$ \\
\hline 4 & 3 & $2.0 \mathrm{a} \doteqdot$ & $20.0 \mathrm{a}$ & $15.0 \mathrm{a}$ & $20.0 \mathrm{a}$ & $25.0 \mathrm{a} \dagger$ & $16.3 \mathrm{a} \ddagger$ & $32.5 \mathrm{a}$ & $982.4 \mathrm{a} \ddagger$ \\
\hline 5 & 1 & $4.5 \mathrm{a}$ & $18.8 \mathrm{a}$ & $20.0 \mathrm{a}$ & $18.8 \mathrm{a}$ & $25.0 \mathrm{a} \dagger$ & $23.8 \mathrm{a} \ddagger$ & $33.8 \mathrm{a}$ & $1082.1 \mathrm{a}+$ \\
\hline 5 & 2 & $3.0 \mathrm{a}$ & $24.5 \mathrm{a}$ & $20.0 \mathrm{a}$ & $18.8 \mathrm{a}$ & $27.5 \mathrm{a} \dagger$ & $21.3 \mathrm{a} \ddagger$ & $32.5 \mathrm{a}$ & $1127.4 \mathrm{a} \neq$ \\
\hline 5 & 3 & $3.0 \mathrm{a}$ & $22.5 \mathrm{a}$ & $16.3 \mathrm{a} \dagger+$ & $18.8 \mathrm{a}$ & $27.5 \mathrm{a} \dagger$ & $17.5 \mathrm{a} \ddagger$ & $30.0 \mathrm{a}$ & $1059.9 \mathrm{a} \ddagger$ \\
\hline 6 & 1 & $5.0 \mathrm{a}$ & $13.8 \mathrm{a} \ddagger$ & $23.8 \mathrm{a}$ & $15.0 \mathrm{a}$ & $22.5 \mathrm{a} \dagger$ & $30.0 \mathrm{ab} \dagger \ddagger$ & $28.8 \mathrm{a}$ & $1036.1 \mathrm{a} \ddagger$ \\
\hline 6 & 2 & $6.3 \mathrm{a}$ & $26.3 \mathrm{a}$ & $17.5 \mathrm{a} \dagger$ & $22.5 \mathrm{a}$ & $31.3 \mathrm{a} \dagger$ & $28.8 \mathrm{ab} \dagger \ddagger$ & $32.5 \mathrm{a}$ & $1299.4 \mathrm{a}$ \\
\hline 6 & 3 & $7.0 \mathrm{a}$ & $26.3 \mathrm{a}$ & $12.5 \mathrm{a} \dagger+$ & $21.3 \mathrm{a}$ & $27.5 \mathrm{a} \dagger$ & $21.3 \mathrm{a} \ddagger$ & $30.0 \mathrm{a}$ & $1157.3 \mathrm{a} \ddagger$ \\
\hline 8 & 1 & $6.5 \mathrm{a}$ & $22.5 \mathrm{a}$ & $25.0 \mathrm{a}$ & $28.0 \mathrm{a}$ & $28.8 \mathrm{a} \dagger$ & $27.5 \mathrm{a} \dagger+$ & $35.0 \mathrm{a} \dagger$ & $1298.9 \mathrm{a}$ \\
\hline 8 & 2 & $4.3 \mathrm{a}$ & $22.5 \mathrm{a}$ & $26.3 \mathrm{a}$ & $22.5 \mathrm{a}$ & $30.0 \mathrm{a} \dagger$ & $21.3 \mathrm{a} \doteqdot$ & $35.0 \mathrm{a} \dagger$ & $1185.4 \mathrm{a} \ddagger$ \\
\hline 8 & 3 & $2.5 \mathrm{a} \ddagger$ & $13.0 \mathrm{a} \ddagger$ & $12.5 \mathrm{a} \dagger+$ & $12.5 \mathrm{a} \dagger \ddagger$ & $17.5 \mathrm{a} \dagger \ddagger$ & $16.3 \mathrm{a} \ddagger$ & $22.5 \mathrm{a}$ & $759.8 \mathrm{a} \ddagger$ \\
\hline 9 & 1 & $4.5 \mathrm{a}$ & $20.5 \mathrm{a}$ & $24.5 \mathrm{a}$ & $21.3 \mathrm{a}$ & $26.3 \mathrm{a} \dagger$ & $46.3 \mathrm{~b} \dagger$ & $33.8 \mathrm{a}$ & $1179.1 \mathrm{a} \ddagger$ \\
\hline 9 & 2 & $4.3 \mathrm{a}$ & $19.5 \mathrm{a}$ & $20.0 \mathrm{a}$ & $18.8 \mathrm{a}$ & $27.5 \mathrm{a} \dagger$ & $30.0 \mathrm{ab} \dagger \ddagger$ & $26.3 \mathrm{a}$ & $1015.9 \mathrm{a} \ddagger$ \\
\hline 9 & 3 & $2.3 \mathrm{a} \ddagger$ & $20.8 \mathrm{a}$ & $15.0 \mathrm{a} \dagger+$ & $17.5 \mathrm{a}$ & $26.3 \mathrm{a} \dagger$ & $15.0 \mathrm{a} \ddagger$ & $27.5 \mathrm{a}$ & $958.6 \mathrm{a} \ddagger$ \\
\hline Pathogen ${ }^{\mathrm{y}}$ & & 13.3 & 30.8 & 33.8 & 31.3 & 38.8 & 37.5 & 38.8 & 1781.6 \\
\hline Fungicide $^{\mathrm{z}}$ & & 9.3 & 26.7 & 33.3 & 28.3 & 4.7 & 11.7 & 16.7 & 1029.3 \\
\hline
\end{tabular}

${ }_{\mathrm{s}}$ Multiple applications refer to the portion of the split plot experimental design that received compost applications every 3 weeks.

${ }^{\mathrm{t}}$ DAT (days after treatment) refers to rating date when disease severity was assessed after initial experimental set up, rated in percent of total plot area diseased.

" Compost refers to compost $4,5,6,8$, or 9 .

${ }^{v}$ Compost application rate: $1=12.2 \mathrm{~kg} / 100 \mathrm{~m}^{2}, 2=24.4 \mathrm{~kg} / 100 \mathrm{~m}^{2}$, and $3=48.7 \mathrm{~kg} / 100 \mathrm{~m}^{2}$.

${ }^{w}$ Values followed by the same letter(s) within individual columns are not statistically different at $P=0.05$, as tested using analysis of variance followed by Tukey's test.

${ }^{x}$ Values followed by the same symbols $(\dagger$ and $\ddagger)$ within individual columns represent treatments that are statistically different $(P=0.05)$ from the fungicide and pathogen controls, respectively.

y Pathogen refers to the level of disease in control plots inoculated with the pathogen only.

${ }^{\mathrm{z}}$ Fungicide refers to the level of disease in control plots treated with the pathogen and a fungicide only. 
highly competitive or antagonistic microorganism populations to new environmental conditions, or release of nutrients and/or its incorporation into soil systems to improve plant health and disease resistance abilities. Lack of consistent differences among compost application rates to suppress dollar spot on individual rating dates may have resulted from levels being applied above those necessary to either adequately inoculate the localized environment with antagonistic or competitive microorganisms, or encourage the growth and activity of resident communities in the turf. However, other causes of lack of differences among application rates may have been due to environmental or plot-to-plot variability, or variability in the distribution of the composts, especially at low levels.

In this experiment, storage of composts for 1 year did not affect their ability to suppress dollar spot disease. Assuming suppression is based partially on microbial activity, the maintenance of aerobic conditions during storage as well as the supply of available nutrients in the composts may maintain populations of microorganisms for extended periods of time. Since suppression of dollar spot has also been postulated to be a result of nitrogen levels, the maintenance of the nitrogen levels in the composts through storage should, therefore, have preserved the ability of compost to suppress disease effectively.

Results of this study support previous findings that composted materials can suppress dollar spot disease development on established turf $(23,28,31,33)$. Other composts and natural organic fertilizers have been found to be highly suppressive to dollar spot when applied preventatively as top-dressings on putting greens (33). Organic amendments such as Ringer Compost Plus and Ringer Greens Restore (Ringer Corporation, Minneapolis, MN) significantly suppressed dollar spot disease development and gave more than $60 \%$ control (28). In other studies, increased microbial populations on turfgrass leaves and in thatch and soil were observed following application of organic amendments (23). Increased competition and antagonism among microbial populations and pathogens has been postulated as a mechanism of disease control.

Top-dressing materials amended with composts and/or organic fertilizers offer an innovative approach to turfgrass disease control programs. Golf course superintendents routinely top-dress greens and tees multiple times over a season with a mixture of sand and some type of organic matter (usually peat) or soil, primarily to smooth the putting surfaces and manage thatch accumulation. The application of compostamended top-dressings for disease management, therefore, would not necessarily introduce additional practices or labor into a turfgrass management program (31). A further reason to replace the sphagnum peat currently used as a top-dressing and organic amendment in the turf industry is because it is a nonrenewable resource from ecological zones described as "the most delicate areas of interaction of vegetation and hydrology on the planet" (39). Covering 3\% of the earth's surface, these areas are crucial to the world's biosphere, and are considered to be on the same scale as the tropical rainforests in importance (39).

Although compost applied in multiple top-dressings is a suitable means of dollar spot management for putting greens, it is unlikely that it will completely replace commercial fungicides for control of dollar spot. However, compost is likely to reduce the incidence and severity of dollar spot to levels that will permit a reduction in the frequency and/or application rates of commercial fungicides. Where dollar spot severity is low, suppressive composts may reduce disease to levels that are acceptable or tolerable to golf course managers, without added chemical control. In addition, composts may become a useful addition to cultural control procedures used in turfgrass disease management programs on golf courses that wish to reduce dependency on chemical controls.

In these experiments, up to five composts made from different feedstocks were tested over a 2-year period, and results showed very few differences among composts in their ability to decrease the severity of dollar spot. It may, therefore, be acceptable for compost producers wishing to create a suppressive product to base all composts on a single feedstock, which would form the majority of batch material, and subsequently add various other feedstocks without altering control capacity. In support of this claim, Hoitink (14) suggested that a broad mechanism of action is responsible for suppression rather than a specific chemical action against pathogens.

The recently established ability of compost to act as a disease suppressant has led to increased research on improving the consistency of control, and increased knowledge or, at least awareness of the large number of factors in composts, which play an integrated role in pathogen suppression.

Table 4. Dollar spot severity (percent disease) in creeping bentgrass plots amended with four composts applied every three weeks at three rates in 1999 (each point is the average of $n=4$ )

\begin{tabular}{|c|c|c|c|c|c|c|c|c|c|c|}
\hline \multirow[b]{2}{*}{ Compost $^{\mathrm{u}}$} & \multirow[b]{2}{*}{ Rate $^{\mathbf{v}}$} & \multicolumn{9}{|c|}{ Days after treatment (DAT) ${ }^{\mathrm{t}}$} \\
\hline & & 29 & 36 & 43 & 50 & 57 & 64 & 71 & 78 & AUDPC \\
\hline $6-1999$ & 1 & $13.3 \mathrm{ab}^{\mathrm{w}} \dagger^{\mathrm{x}}$ & $26.3 \mathrm{bcd}$ & $30.0 \mathrm{~d} \ddagger$ & $15.0 \mathrm{abcd}$ & $26.3 \mathrm{c} \neq$ & $28.8 \mathrm{c} \dagger \ddagger$ & $20.0 \mathrm{~cd} \dagger \ddagger$ & $25.0 \mathrm{bc} \dagger \ddagger$ & $1239.0 \mathrm{bc} \ddagger$ \\
\hline $6-1999$ & 2 & $5.8 \mathrm{cde} \dagger$ & $20.0 \mathrm{abcd}$ & $20.0 \mathrm{abcd}$ & $13.8 \mathrm{abcd}$ & $20.0 \mathrm{abc}$ & $17.5 \mathrm{abc} \dagger$ & $10.0 \mathrm{abc} \dagger \ddagger$ & $10.0 \mathrm{abc} \dagger \dagger$ & $706.1 \mathrm{ab} \ddagger$ \\
\hline $6-1999$ & 3 & 4.5 cde $\ddagger$ & $7.0 \mathrm{a} \dagger \ddagger$ & $6.3 \mathrm{a} \dagger+$ & $2.5 \mathrm{ab} \dagger \ddagger$ & $6.3 \mathrm{ab}$ & $7.5 \mathrm{a} \ddagger$ & $3.8 \mathrm{ab} \ddagger$ & $5.0 \mathrm{ab} \ddagger$ & $295.8 \mathrm{a} \dagger \dagger$ \\
\hline $9-1999$ & 1 & 8.5 cde $\dagger \ddagger$ & $26.3 \mathrm{bcd}$ & $26.3 \mathrm{~cd} \ddagger$ & $20.0 \mathrm{~cd} \doteqdot$ & $32.5 \mathrm{c} \ddagger$ & $26.3 \mathrm{bc} \neq$ & $20.0 \mathrm{~cd} \ddagger$ & $23.8 \mathrm{bc} \neq$ & $1232.0 \mathrm{bc} \neq$ \\
\hline $9-1999$ & 2 & $2.8 \mathrm{e} \ddagger$ & $20.0 \mathrm{abcd}$ & 20.0 abcd $\ddagger$ & 11.3 abcd $\ddagger$ & $22.5 \mathrm{bc} \neq$ & $20.0 \mathrm{abc} \dagger+$ & $7.5 \mathrm{abc} \dagger+$ & $11.3 \mathrm{abc} \dagger \dagger$ & $777.0 \mathrm{ab} \ddagger$ \\
\hline $9-1999$ & 3 & $3.5 \mathrm{de} \dagger+$ & $8.8 \mathrm{ab} \dagger \ddagger$ & $7.5 \mathrm{ab} \neq$ & $0.0 \mathrm{a} \dagger \ddagger$ & $5.0 \mathrm{a} \div$ & $7.5 \mathrm{a} \neq$ & $1.3 \mathrm{a} \neq$ & $5.0 \mathrm{~b} \ddagger$ & $260.8 \mathrm{a} \dagger \dagger$ \\
\hline $6-1998$ & 1 & 8.0 bcde $\ddagger$ & $31.3 \mathrm{~cd}$ & $27.5 \mathrm{~cd} \ddagger$ & $21.3 \mathrm{~d} \ddagger$ & $25.0 \mathrm{c} \ddagger$ & $27.5 \mathrm{bcd} \ddagger$ & $17.5 \mathrm{bcd} \ddagger$ & $21.3 \mathrm{abc} \neq$ & $1211.0 \mathrm{bc} \ddagger$ \\
\hline $6-1998$ & 2 & 4.5 cde $\ddagger$ & $22.5 \mathrm{abcd}$ & 22.5 abcd $\ddagger$ & 8.8 abcd $\ddagger$ & $20.0 \mathrm{abc} \ddagger$ & $17.5 \mathrm{abc} \ddagger$ & $8.8 \mathrm{abc} \ddagger$ & $12.0 \mathrm{abc} 末$ & $794.5 \mathrm{ab} \neq$ \\
\hline $6-1998$ & 3 & 3.8 cde & $12.5 \mathrm{abc}$ & $11.3 \mathrm{abc} \ddagger$ & $5.0 \mathrm{abc}$ & $7.5 \mathrm{ab} \ddagger$ & $10.0 \mathrm{ab} \ddagger$ & $3.8 \mathrm{ab} \doteqdot$ & $1.3 \mathrm{a} \ddagger$ & $396.4 \mathrm{a} \ddagger$ \\
\hline $9-1998$ & 1 & $17.5 \mathrm{a} \ddagger$ & $38.8 \mathrm{~d}$ & $28.8 \mathrm{~d} \doteqdot$ & $22.5 \mathrm{~d} \ddagger$ & $32.5 \mathrm{c} \ddagger$ & $33.8 \mathrm{~d} \ddagger$ & $25.0 \mathrm{~d} \ddagger$ & $28.8 \mathrm{c} \ddagger$ & $1538.3 c \dagger \ddagger$ \\
\hline $9-1998$ & 2 & $9.3 \mathrm{bc}$ & $27.5 \mathrm{bcd}$ & $28.8 \mathrm{~d}$ & $17.5 \mathrm{bcd} \ddagger$ & $22.5 b c \neq$ & 28.8 abcd $\dagger \ddagger$ & $15.0 \mathrm{abcd} \dagger \ddagger$ & $20.0 \mathrm{abc} \dagger \dagger$ & $1152.4 b c \ddagger$ \\
\hline $9-1998$ & 3 & 3.8 cde $\dagger+$ & $11.3 \mathrm{ab} \dagger+$ & $10.0 \mathrm{ab} \ddagger$ & $4.0 \mathrm{ac} \dagger \ddagger$ & $7.5 \mathrm{ab} \neq$ & $8.8 \mathrm{a} \dagger+$ & $1.3 \mathrm{a} \div$ & $2.5 \mathrm{a} \ddagger$ & $352.6 \mathrm{a} \dagger+$ \\
\hline Pathogen ${ }^{y}$ & & 17.5 & 36.3 & 45.0 & 43.8 & 45.0 & 48.8 & 57.5 & 63.8 & 2319.6 \\
\hline Fungicide $^{z}$ & & 11.3 & 31.3 & 21.3 & 27.5 & 15.0 & 10.0 & 7.5 & 6.3 & 903.0 \\
\hline
\end{tabular}

${ }^{t}$ DAT (days after treatment) refers to rating date when disease severity was assessed after initial experimental set up, rated in percent of total plot area diseased.

u Compost refers to compost 6 or 9 prepared in 1998 or 1999.

${ }^{\mathrm{v}}$ Compost application rate: $1=12.2 \mathrm{~kg} / 100 \mathrm{~m}^{2}, 2=24.4 \mathrm{~kg} / 100 \mathrm{~m}^{2}$, and $3=48.7 \mathrm{~kg} / 100 \mathrm{~m}^{2}$.

w Values followed by the same letter(s) within individual columns are not statistically different at $P=0.05$, as tested using analysis of variance followed by Tukey's test.

${ }^{\mathrm{x}}$ Values followed by the same symbols $(\dagger$ and $\ddagger)$ within individual columns represent treatments that are significantly different $(P=0.05)$ from the fungicide and pathogen, respectively.

y Pathogen refers to the level of disease in control plots inoculated with the pathogen only.

${ }^{\mathrm{z}}$ Fungicide refers to the level of disease in control plots treated with the pathogen and a fungicide only. 


\section{LITERATURE CITED}

1. Abad, Z. G., Shew, H. D., and Lucas, L. T. 1994. Characterization and pathogenicity of Pythium species isolated from turfgrass with symptoms of root and crown rot in North Carolina. Phytopathology 84:913-921.

2. Boulter, J. I., Boland, G. J., and Trevors, J. T. 2000. Compost: A study of the development process and end-product potential for suppression of turfgrass disease. World J. Microbiol. \& Biotechnol. 16:115-134.

3. Burpee, L. L., Kaye, L. M., Goulty, L. G., and Lawton, M. B. 1987. Suppression of gray snow mold on creeping bentgrass by an isolate of $T y$ phula phacorrhiza. Plant Dis. 71:97-100.

4. Chen, W., Hoitink, H. A. J., and Madden, L. V. 1988. Microbial activity and biomass in container media for predicting suppressiveness to damping-off caused by Pythium ultimum. Phytopathology 78:1447-1450.

5. Chen, W., Hoitink, H. A. J., Schmitthenner, F., and Tuovinen, O. H. 1988. The role of microbial activity in suppression of damping-off caused by Pythium ultimum. Phytopathology 78:314-322.

6. Couch, H. B. 1995. Diseases of Turfgrasses. 3rd ed. Krieger Publishing Company, Malabar, Florida.

7. Craft, C. M. and Nelson, E. B. 1992. A miniaturized and rapid bioassay for the selection of soil bacteria suppressive to pythium blight of turfgrasses. Phytopathology 82:206-210

8. Craft, C. M. and Nelson, E. B. 1996. Microbial properties of compost that suppress damping-off and root rot of creeping bentgrass caused by Pythium graminicola. Appl. Environ. Microbiol. 62:1550-1557.

9. Davis, C. L., Donkin, C. J., Hinch, S. A., and Germishuizen, P. 1992. The microbiology of pine bark composting: an electron-microscope and physiological study. Bioresour. Technol. 40:195-204.

10. Di Pietro, A., Gut-Rella, M., Pachlatko, J. P., and Schwinn, F. J. 1992. Role of antibiotics produced by Chaetomium globosum in biocontrol of Pythium ultimum, a causal agent of damping-off. Phytopathology 82:131-135.

11. Goodman, D. M. and Burpee, L. L. 1991. Biological control of dollar spot disease of creeping bentgrass. Phytopathology 81:14381446.

12. Henis, Y. and Chet, I. 1975. Microbial control of plant pathogens. Adv. Appl. Microbiol. 19:85-111

13. Hodges, C. F., Campbell, D. A., and Christians, N. 1994. Potential biocontrol of Sclerotinia homoeocarpa and Bipolaris sorokiniana on the phylloplane of Poa pratensis with strains of Pseudomonas spp. Plant
Pathol. 43:500-506.

14. Hoitink, H. A. J. 1980. Composted bark, a lightweight growth medium with fungicidal properties. Plant Dis. 64:142-147.

15. Hoitink, H. A. J. and Fahy, P. C. 1986. Basis for the control of soilborne plant pathogens with composts. Annu. Rev. of Phytopathol. 24:93-114

16. Hoitink, H. A. J., Inbar, Y., and Boehm, M. J. 1993. Compost can suppress soil-borne diseases in container media. Am. Nurseryman 178:91-94.

17. Hoyland, B. F. and Landschoot, P. J. 1993. Effect of various nitrogen $(\mathrm{N})$ sources on dollar spot suppression. Biol. and Cult. Tests Control Plant Dis. 8:112.

18. Huber, D. M. 1980. The role of mineral nutrition in defense. Pages 381-406 in: Plant Disease an Advanced Treatsie, J. G. Horsfall, and E. B. Cowling, eds. Vol. V. Academic Press, New York, NY

19. Ko, W. and Lockwood, J. L. 1970. Mechanism of lysis of fungal mycelia in soil. Phytopathology 60:148-154.

20. Landschoot, P. J. and McNitt, A. S. 1997. Effect of nitrogen fertilizers on suppression of dollar spot disease of Agrostis stolonifera L. Int. Turfgrass Soc. Res. J. 8:905-911.

21. Lawton, M. B. and Burpee, L. L. 1990. Effect of rate and frequency of application of $T y$ phula phacorrhiza on biological control of typhula blight of creeping bentgrass. Phytopathology 80:70-73.

22. Little, T. M. and Hills, F. J. 1978. Agricultural Experimentation Design and Analysis. John Wiley and Sons, Inc., New York.

23. Liu, L. X., Hsiang, T., Carey, K., and Eggens, J. L. 1995. Microbial populations and suppression of dollar spot disease in creeping bentgrass with inorganic and organic amendments. Plant Dis. 79:144-147.

24. Lockwood, J. L. 1986. Soilbourne plant pathogens: concepts and connections. Phytopathology 76:20-27.

25. Lockwood, J. L. and Filonow, A. B. 1981. Responses of fungi to nutrient-limiting conditions and to inhibitory substances in natural habitats. Adv. Microb. Ecol. 5:1-61.

26. Lorito, M., Peterbauer, C., Hayes, C. K., and Harman, G. E. 1994. Synergistic interaction between fungal cell wall degrading enzymes and different antifungal compounds enhances inhibition of spore germination. Microbiology 140:623-629.

27. Lucas, J. A. 1998. Plant pathology and plant pathogens. 3rd ed. Blackwell Science, Ltd. London, UK.

28. Nakasaki, K., Hiraoka, S., and Nagata, H. 1998. A new operation for producing disease- suppressive compost from grass clippings. Appl. Environ. Microbiol. 64:4015-4020.

29. Nelson, E. B. 1991. Introduction and establishment of strains of Enterobacter cloacae in golf course turf for the biological control of dollar spot. Plant Dis. 75:510-514.

30. Nelson, E. B. 1992. The Biological Control of Turfgrass Diseases. Page 10 in: Golf Course Management. March 1992.

31. Nelson, E. B. and Craft, C. M. 1991. Suppression of dollar spot with topdressings amended with composts and organic fertilizers, 1989. Biol. Cult. Tests Control Plant Dis. 6:93.

32. Nelson, E. B. and Craft, C. M. 1991. Suppression of red thread with topdressings amended with composts and organic fertilizers, 1989. Biol. Cult. Tests Control Plant Dis. 6:101.

33. Nelson, E. B. and Craft, C. M. 1992. Suppression of dollar spot on creeping bentgrass and annual bluegrass turf with compost-amended topdressings. Plant Dis. 76:954-958.

34. O'Sullivan, D. and O'Gara, F. 1992. Traits of fluorescent Pseudomonas spp. involved in suppression of plant root pathogens. Microbiol. Rev. 56:662-676.

35. Phae, C. G., Sasaki, M., Shoda, M., and $\mathrm{Ku}$ bota, H. 1990. Characteristics of Bacillus subtilis isolated from composts suppressing phytopathogenic microorganisms. Soil Sci. Plant Nutr. 4:575-586.

36. Shanner, G. and Finney, R. E. 1977. The effect of nitrogen fertilization on the expres sion of sow-mildewing resistance in Knox wheat. Phytopathology 67:1051-1056.

37. Smiley, R. W., Dernoeden, P. H., and Clarke, B. B. 1992. Compendium of Turfgrass Diseases. 2nd ed., The American Phytopathological Society, St. Paul, MN

38. Tooley, P. W. and Grau, C. R. 1984. Field characterization of rate-reducing resistance to Phytophthora megasperma f. sp. glycinea in soybean. Phytopathology 74:1201-1208.

39. Underwood, C. 1992. The Nature of Things: The Hidden World of the Bog. Ottawa, Ontario, Canada: Canadian Broadcasting Corporation, CBC International Sales.

40. Van Dijk, K. and Nelson, E. B. 1998. Inactivation of seed exudate stimulants of Pythium ultimum sporangium germination by bioconrol strains of Enterobacter cloacae and other seed-associated bacteria. Soil Biol. Biochem. 30:183-192.

41. Walsh, B. Ikeda, S. S , and Boland, G. J. 1999. Biology and management of dollar spot (Sclerotinia homoeocarpa); an important disease of turfgrass. HortScience 34:13-21

42. Whipps, J. M. 1997. Developments in the biological control of soil-borne plant pathogens. Adv. Bot. Res. Vol 26, Pages 1-134. 